\title{
PEMBUATAN GERABAH TRADISIONAL DI PULAU BAWEAN: TINJAUAN TENTANG ASAL DAN HUBUNGAN SIMBIOTIK DENGAN BEBERAPA DAERAH DI INDONESIA
}

\section{Goenadi Nitihaminoto}

Keywords: pottery; tradition; technique; ethnography; earthenware

How to Cite:

Nitihaminoto, G. (1988). PEMBUATAN GERABAH TRADISIONAL DI PULAU BAWEAN: TINJAUAN TENTANG ASAL DAN HUBUNGAN SIMBIOTIK

DENGAN BEBERAPA DAERAH DI INDONESIA. Berkala Arkeologi, 9(1), 1-16. https://doi.org/10.30883/jba.v9i1.494

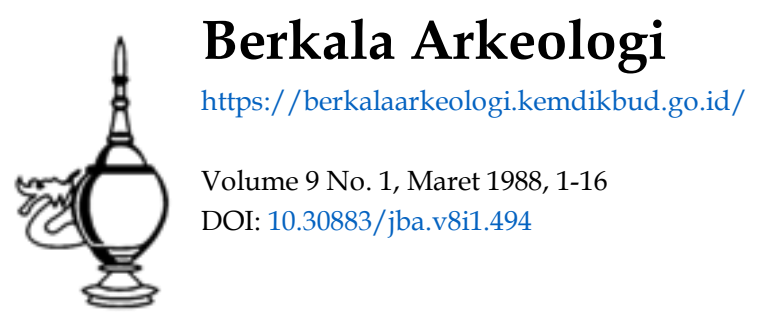




\section{PEMBUATAN GERABAH TRADISIONAL DI PULAU \\ BAWEAN: TINJAUAN TENTANG ASAL DAN \\ HUBUNGAN SIMBIOTIK DENGAN BEBERAPA \\ DAERAH DI INDONESIA}

Goenadi Nitihaminoto

Bawean merupakan pulau kecil \$seluas $19.411,355 \mathrm{Km}^{2}$ yang terletak lebih kurang 150 kilometer di sebelah utara Gresik, Jawa Timur. Secara administratif pulau ini masuk ke dalam kabupaten Gresik dan secara geografis terletak antara $112^{\circ} 33^{\prime} 00^{\prime \prime}$ sampai $112^{\circ} 43^{\prime} 55^{\prime \prime}$ Bujur Timur dan antara $5^{\circ} 42^{\prime} 49^{\prime \prime}$ sampai $5^{\circ} 51^{\prime} 00^{\prime \prime}$ Lintang Selatan, meredian Greenwich. ${ }^{1}$

Pulau ini dibagi menjadi dua daerah kecamatan, yaitu kecamatan Sangkapura di bagian Selatan dan kecamatan Tambak di belahan utara. Daerah ini hanya dapat dicapai dengan kapal motor, yang memakan waktu antara 10 hingga 14 jam perjalanan dari pelabuhan Gresik. Jalan darat di pulau itu terdapat sepanjang pantai, yaitu sepanjang 55 kilometer dengan kondisi tidak terlalu baik, namun dapat dilewati kendaraan bermotor.

Pada tahun 1984 Pulau Bawean berpenduduk 66.225 jiwa yang semuanya beragama Islam. Bahasa daerah yang digunakan adalah bahasa Bawean hampir sama dengan bahasa Madura yang digunakan oleh penduduk pulau Kangean. Pengecualian penggunaan bahasa ini terdapat pada penduduk desa Diponggo, kecamatan Tambak. Masyarakat di desa ini menggunakan bahasa daerah Jawa dalam percakapan sehari-hari.

IPengukuran diperoleh dari peta Jawa \& Madura, skala $1: 500.000$ terbitan P.T. Pembina 1974/1975.

Berkala Arkeologi IX (1) 
Mata pencaharian penduduk Bawean adalah bercocok tanam, baik di sawah atau di ladang. Selain itu mereka hidup sebagai nelayan, pedagang, undagi, dan pegawai negeri. Mereka juga membuat anyaman dari daun pandan sebagai mata pencaharian. Penduduk pulau ini banyak yang merantau ke Singapura dan Malaysia. Tidak dapat diketahui dengan pasti, sejak kapan mereka mulai merantau ke daerah itu. Menurut sumber disebutkan bahwa pada abad ke-19 telah ada penduduk Bawean yang kembali dari Singapura (R. Abdurrachman Badruddin, 1985: 1-6).

Hubungan antara Bawean dengan Jawa dilakukan melalui Gresik dan Tuban, di Jawa Timur. Adanya hubungan dengan ke dua daerah itu adalah untuk mencukupi kebutuhan mereka sehari-hari, yaitu perdagangan dan kegiatan lainnya. Para nelayan dan pedagang Bawean yang datang ke Tuban umumnya melakukan perdagangan. Nelayan-nelayan itu membeli gerabah berkapal-kapal dari Tuban untuk wadah ikan laut yang mereka tangkap.

Dilihat dari keletakannya, pulau Bawean berada hampir di tengah laut Jawa, yaitu di antara pulau-pulau besar seperti Kalimantan, Sulawesi, Jawa, dan pulau pulau lain di sekitarnya. Dengan demikian pulau Bawean dapat dianggap sangat strategis. Di bidang perdagangan, pulau ini merupakan suatu pulau transit, tempat persinggahan para pedagang dari pulau-pulau di sebelah utaranya. Hubungan dagang tersebut mungkin akan menyebabkan pengaruh di bidang sosial budaya. Bertolak dari anggapan tersebut, maka keadaan sosial dan budaya di pulau Bawean tentunya mengalami perubahan-perubahan tertentu. Meskipun demikian kondisi sosial budaya di pulau itu dapat juga tidak mengalami perubahan, tergantung pada proses evolusi sosial budaya yang ada di daerah itu; baik proses mikroskopik atau makroskopik.

Pembuatan gerabah di pulau Bawean merupakan salah satu bentuk budaya tradisional yang masih hidup hingga saat ini. Secara umum dapat diperkirakan bahwa pengaruh hubungan antarsuku dengan daerah-daerah di luar pulau mengakibatkan perubahanteknik 
pembuatan gerabah di daerah itu. Teknik pembuatan gerabah dapat juga tidak mengalami perubahan, walaupun hubungan dengan daerah lain sudah berlangsung sejak lama dan intensif. Untuk mengungkapkan ada tidaknya perubahân-perubahan itu, perlu diadakan perban dingan teknik penbuatan gerabah dengan daerah-daerah yang sering mengadakan kontak dengan Bawean. Dengan demikian akan dapat diketahui sifat hubungan yang terjalin antara Bawean dengan beberapa daerah tersebut di atas.

Pembuatan gerabah di pulau Bawean terletak di dukuh Disalam, kelurahan Patarselamat, sekitar 2 kilometer di sebelah Utara Sangkapura. Di pedukuhan ini terdapat 6 keluarga yang masih membuat gerabah (tukang kete) sebagai mata pencaharian sambilan. Mereka membuat gerabah berdasarkan pesanan atau untuk mencukupi kebutuhan sendiri. Dalam pembuatan gerabah di daerah ini tidak digunakan perbot (potter's wheel) seperti yang digunakan di Jawa atau daerah Indonesia bagian barat lainnya. Dalam pembuatan gerabah mereka memakai metode tangan yang dipadukan dengan tatap pelandas (paddle and anvil).

Peralatan. Alat-alat yang digunakan dalam pembuatan gerabah masih sangat sederhana, terdiri atas peen (papan), palu-palu, batu. lampen (kain), kerek-kerek, gusok-gusok dan pamelet. Peen, merupakan papan kayu rata dengan bermacam-macam ukuran, térgantung pada ukuran gerabah yang akan dibuat. Di antaranya ada yang berukuran $34 \mathrm{~cm} \times 22 \mathrm{~cm} \times 1 \mathrm{~cm}$. Peen digunakan untuk meletakkan pekal dalam proses awal pembuatan gerabah. Palu-palu (paddle) dibuat dari sepotong papan kayu dengan pegangan pada bagian pangkal. Panjarig pegangan adalah setengah dari panjang seluruh papan kayu itu. Palu-palu mempunyai beberapa ukuran di antaranya adalah $28 \mathrm{~cm} \times 13 \mathrm{~cm} \times 1 \mathrm{~cm}$ dengan ukuran pegangan $14 \mathrm{~cm} \times 4 \mathrm{~cm} \times 1 \mathrm{~cm}$. Palu-palu digunakan untuk memukul dinding gerabah yang masih basah untuk menambah ukuran. 
Batu biasanya diambil dari batu kali berbentuk bulat telur dengan berbagai ukuran. Ukuran umum yang dipakai biasanya $8 \mathrm{~cm} \times 6 \mathrm{~cm}$ $\times 3 \mathrm{~cm}$ dan digunakan untuk menahan dinding periuk bagian dalam pada waktu dinding luar dipukul dengan palu-palu. Lampen dibuat dari kain bekas, daun pisang kering, atau plastik tanpa ukuran tertentu. Lampen dipakai untuk alas pangkuan supaya tidak kotor oleh gerabah yang dipukul dengan palu-palu. Selain itu lampen juga digunakan sebagai alas bahan yang kemudian diletakkan di atas peen. Kerek-kerek digunakan untuk menipiskan dinding gerabah yang masih basah, dibuat dari serpihan bambu yang dibentuk bulat dengan menyatukan kedua ujungnya. Sekarang kerek-kerek dibuat dari logam bulat tipis, seperti bingkai senter dan sebagainya. Gusokgusok dibuat dari sejenis kerang, digunakan untuk menghaluskan dinding gerabah bagian dari bekas-bekas yang ditinggalkan oleh batu. Pamelet adalah secarik kain bekas yang dibasahi untuk meratakan dinding gerabah dan membentuk bibir.

Proses Pembuatan. Bahan baku yang digunakan dalam pembuatan gerabah di daerah ini terdiri atas tanah liat yang dicampur pasir. Tanah liat diambil dari kebun. sedang pasir diambil dari sungai di dekat hunian mereka. Tanah liat kemudian dicampur dengan pasir yang telah disaring, ditambah sedikit air, dan diremas-remas sampai mencapai kepekatan tertentu. Proses pengolahan bahan baku ini disebut ngocel. Tanah yang telah dicampur pasir ini disebut pekal, diambil secukupnya kemudian diletakkan di atas peen, dan dimulailah proses pembentukan gerabah.

Pekal diletakkan di atas lampen dialasi peen. Kemudian pekal dipukul-pukul dengan tangan dan dikeruk-keruk dengan jari jemari sambil diputar sedikit demi sedikit. Pada waktu pekal diputar sedikit demi sedikit sambil diangkat, lampen ikut berputar karena melekat pada pekal. sedang peen tetap tidak bergerak. Dalam proses awal ini terbentuklah bentuk dasar badan gerabah tanpa bibir. Kemudian bagian dalam dan luarnya diratakan dengan pamelet. Pembentukan bibir gerabah dilakukan dengan cara menjepit bagian atas badan gerabah dengan dua jari yang telah dialasi pamelet. ditekuk ke luar 
sambil diputar sedikit demi sedikit. Setelah gerabah terbentuk, ke mudian diangin-anginkan sehingga gerabah itu menjadi lebih keras.

Setelah cukup kering, dinding gerabah bagian luar kemudian dipukul dengan palu-palu dan dinding bagian dalam ditahan dengan batu. Selama proses pemukulan dinding gerabah itu, batu dan palupalu selalu diolesi air supaya tidak melekat pada dinding gerabah tersebut. Pemukulan dinding gerabah ini dimaksudkan untuk memperbesar ukuran dan meratakan dinding gerabah. Dalam pemukulan ini kadang-kadang dijumpai kerikil-kerikil kecil, yang akan mengurangi porositas dinding gerabah bila tidak dibuang. Setelah proses pemukulan dianggap cukup, maka gerabah diangin-anginkan lagi pada tempat yang teduh. Bila dinding gerabah itu telah dianggap cukup kuat, kemudian diratakan dengan gusok-gusok, dan akhirnya dijemur langsung di bawah sinar matahari. Apabila gerabah telah menjadi kering benar, digosok dengan gusok-gusok hingga mengkilat. Penggosokan ini dimaksudkan untuk merapatkan pori-pori dinding gerabah sehingga kedap air.

Gerabah-gerabah yang telah kering dan telah dihaluskan dengan gusok-gusok kemudian dibakar. Gerabah-gerabah itu disusun terbalik sampai 4-5 lapis di atas kayu kering, kemudian ditutup lagi dengan beberapa bahan bakar kayu atau jerami sehingga mencapai ketebalan tertentu. Setelah itu tumpukan jerami dibakar, yang memakan waktu antara 1 sampai $2 \mathrm{jam}$. Apabila bahan bakar habis sebelum gerabah masak, ditambahkan bahan bakar lagi hingga mencapai keadaan yang diinginkan.

Jenis-jenis gerabah. Jenis-jenis gerabah yang dihasilkan di dukuh Disalam tidak terlalu banyak, yaitu belanga, kete, sangaran, dan pela, yang umumnya berdasar bulat. Belenga adalah periuk yang berukuran agak besar, yaitu garis tengah mulut $36 \mathrm{~cm}$, tinggi $36 \mathrm{~cm}$, dan tebal dinding $2 \mathrm{~cm}$. Kete berbentuk seperti belanga dengan ukuran lebih kecil, yaitu tinggi $11 \mathrm{~cm}$, garis tengah mulut $18 \mathrm{~cm}$, tebal dinding $0,5 \mathrm{~cm}$. Belanga dan kete digunakan untuk memasak makanan, tempat air, dan sebagainya. Selain itu kete digunakan pula untuk tempat memindang ikan. 
Sangaran berbentuk seperti wajan, digunakan untuk menggoreng kopi. Ukuran sangaran adalah tinggi $9 \mathrm{~cm}$, diameter mulut $34 \mathrm{~cm}$, dan tebal $1,2 \mathrm{~cm}$. Pela bentuknya seperti cowek di Jawa, digunakan sebagai alat dapur khususnya untuk melumatkan bumbubumbu masak. Pela berukuran tinggi $4 \mathrm{~cm}$, diameter $25 \mathrm{~cm}$, tebal $0,6 \mathrm{~cm}$.

\section{III}

Secara umum metode pembuatan gerabah yang dikenal hingga sekarang ada 4 macam, yaitu metode tangan (hand modelled), metode lingkaran (coiling), metode roda pemutar (potter's wheel), dan metode cetakan (moulding). Dari keempat metode itu, metode tangan merupakan metode yang paling sederhana, sehingga dianggap metode yang tertua di antara metode lainnya. Keempat jenis metode pembuatan gerabah itu masih dijumpai di Indonesia, khususnya di Jawa, sedangkan di daerah-daerah lain hanya digunakan salah satu metode tertentu saja. Metode-metode itu dianggap sebagai suatu tradisi yang berasal dari zaman prasejarah yang masih hidup hingga saat ini.

Di beberapa negara di luar Indonesia keempat metode itu masih ditemukan di Jepang dan Nigeria; metode lingkaran ditemukan juga di Jepang, yaitu di Takunabe, untuk membuat gerabah berukuran besar (Leach, t.t: 63; 122). Metode roda pemutar masih digunakan di beberapa negara di dunia ini. Metode ini diduga berasal dirri Timur Dekat, kurang lebih pada 3000 SM yang kemudian tersebar ke Mesir dan Cina (Norton, 1956: 85). Penyebaran metode roda pemutar ini sampai ke daerah Alpen Utara, Skotlandia, dan Eropa (Childe, 1956: 122). Metode cetakan masih digunakan di Cina (Leach, t.t.: 95-96).

Di Indonesia, metode tangan umumnya dipadukan dengan peng. gunaan tatap pelandas. Metode ini banyak dijumpai di daerah Indonesia bagian tengah dan Indonesia bagian timur, meskipun be berapa dijumpai di Indonesia bagian barat. Di Sulawesi misalnya, 
metode ini ditemukan di Sulawesi Utara, Sulawesi Tengah, dan Sulawesi Selatan. Di Sulawesi Utara metode ini masih digunakan di desa Pulutan, kabupaten Minahasa (Santosa Sugondo, 1981: 11-44). Di Sulawesi Tengah masih dipakai oleh orang-orang Toraja Barat (van Heekeren, 1972: 171), dan di Sulawesi Selatan metode itu ditemukan di Berru, Cabbenge (Soejono, 1979: 1-3). Di Daerah Indonesia bagian tengah lainnya, metode tangan yang dipadukan dengan tatap pelandas ditemukan di pulau-pulau Sumbawa, Flores, dan Timor. Di pulau Sumbawa, khususnya di Sumbawa Timur pembuatan gerabah dengan metode tangan terdapat di dekat Raba (M.M. Sukarto KA, 1973: 71-74), sedangkan di Flores Timur ditemukan di Nualela, pulau Lomblen (Sumiati As, 1983: 1- 15) dan di Timor ditemukan di desa Oralan, Timor Timur (Glcver, 1968: 77-82).

Di Indonesia bagian timur pembuatan gerabah dengan metode tangan dijumpai di pulau Mansinam (Manokwari) dan di kampung Abar, daerah Danau Sentani, Jayapura. Pembuatan periuk dengan metode ini hampir punah, karena hanya dilakukan berdasarkan pesanan atau untuk memenuhi kebutuhan sendiri (Goenadi Nh, 1980: 19-21).

Di daerah Indonesia bagian barat, pembuatan gerabah dengan metode tangan hanya terdapat di beberapa daerah di Jawa dan Sumatera. Di Jawa metode itu ditemukan di Madura (Goenadi Nh, 1971: 19) dan di daerah Jawa Barat yaitu di daerah Garut, sedangkan di Sumatera pembuatan gerabah dengan metode tangan ditemukan di Gayo, pedalaman Aceh (Soejono, 1977: 273-274).

Bila diperhatikan, pembuatan gerabah dengan metode roda pemutar banyak dijumpai di Indonesia bagian barat, meskipun di beberapa daerah terdapat metode gerabah lain seperti coiling dan cetakan. Metode coiling juga dipadukan dengan metode lain, seperti metode tangan, atau metode roda pemutar dan dibantu dengan tatap pelandas. Metode coiling yang digabungkan dengan metode tangan dijumpai di Garut, Jawa Barat (RP Soejono, 1977: 274) sedangkan metode cetakan masih digunakan di daerah Bojonegoro, 
Jawa Timur, untuk membuat mainan anak-anak (Goenadi Nh, 1971: 11). Kedua metode di atas sampai saat ini hanya terbatas di Jawa dan keberadaannya sangat langka.

Dari uraian tersebut di atas, ternyata bahwa pembuatan gerabah di pulau Bawean termasuk dalam kelompok metode pembuatan gerabah di Indonesia bagian tengah dan timur. Untuk dapat menjelaskan perbedaan metode pembuatan gerabah di pulau Bawean dengan daerah-daerah di Indonesia bagian barat, perlu ditinjau asal metode itu. Dalam meninjau asal metode tersebut akan dikemukakan terlebih dahulu tentang asal penduduk asli daerah itu.

Dua suku bangsa yang menghuni pulau Bawean saat ini, belum tentu merupakan penduduk asli pulau itu. Sebagian penduduk menggunakan bahasa daerah Jawa, sedangkan sisanya menggunakan bahasa Bawean dalam percakapan sehari-harinya. Belum diketahui suku bangsa mana yang lebih dahulu menghuni pulau itu. Terdapat beberapa kemungkinan dalam menafsirkan awal penghunian pulau Bawean. Sebelum kedatangan penduduk yang sekarang, mungkin pulau ini telah dihuni penduduk asli, yang kemudian berasimilasi dan akhirnya menjadi penduduk yang berbahasa Bawean sekarang. Kemungkinan lain, pulau itu pada awalnya tidak berpenghuni, kemudian dua suku bangsa tersebut datang dan menjadi penduduk Bawean yang sekarang.

Pembuatan gerabah di Bawean dilakukan oleh sekelompok penduduk yang menggunakan bahasa Bawean. Bahasa tersebut mirip dengan bahasa Madura, khususnya yang digunakan oleh penduduk pulau Kangean. Dengan adanya kenyataan ini diduga bahwa suatu ketika sekelompok penduduk dari daerah Madura bermigrasi ke daerah ini dan selanjutnya menetap. Dalam migrasi itu mereka, khususnya para wanita, sebagian membawa konsep ide pembuatan gerabah. Di tempat hunian baru, mereka tetap membuat gerabah untuk kepentingan sehari-hari. Perkiraan ini ditunjang dengan adanya persamaan metode pembuatan gerabah antara Bawean dengan Madura. Di samping itu, suku Madura memang dikenal sebagai suku bangsa yang suka bekerja giat dan merantau. 
Pembuatan gerabah di pulau Bawean dengan menggunakan metode tangan yang dipadukan dengan tatap pelandas, dapat pula dihutungkan dengan adanya migrasi bangsa yang mungkin melewati Philipina, kemudian menyebar ke arah selatan, seperti Sulawesi. dan lama kelamaan menyebar ke arah selatan, timur, dan mungkin pula ke arah Barat. Dugaan ini ditunjang pula dengan adanya persamaan nama-nama gerabah di Bawean dengan daerah Philipina. Selain itu, sebagian besar metode pembuatan gerabah di Philipina sama dengan yang ada di pulau Bawean.

Dalam pembuatan gerabah di Philipina digunakan alat-alat yang relatif sederhana, sehingga perbot (potter's wheel) belum digunakan secara intensif. Mereka juga menggunakan papan dalam proses pembuatan gerabah. Alat-alat lain yang digunakan ialah bato (batu). palpal (palu-palu), dan kulit kerang untuk menggosok gerabah sebelum dibakar, yang disebut tuway. Hasil-hasilnya antara lain adalah balangan. balanga (belenga). palayok (periuk). kawali (kuwali/Jawa). dan paso (pasu). Salah satu sumber menyebutkan bahwa pembuatan gerabah di daerah ini dipengaruhi oleh Cina (Schieans, 1977: 41-117).

\section{IV}

Penyebaran beberapa unsur budaya disebabkan karena adanya migrasi, kontak dagang, perkawinan. dan sebagainya. Faktor-faktor tersebut dapat menyebabkan berubahnya budaya setempat atau dapat pula hidup berdampingan tanpa saling mempengaruhi. Apabila budaya setempat terpengaruh, maka timbullah budaya campuran. Sedangkan apabila unsur-unsur budaya setempat tidak berubah meskipun menerima pengaruh budaya luar, maka hubungan seperti ini disebut hubungan simbiotik (Koentjaraningrat, 1981: 259).

Kemungkinan adanya perpindahan orang-orang Madura ke pulau Bawean. menyebabkan daerah ini mengenal cara-cara pembuatan gerabah yang sama dengan daerah asalnya. Kemungkinan lain adalah bahwa pembuatan gerabah di Bawean tidak berubah, sedangkan hubungan dagang berlangsung sejak lama dan terus- 
menerus dengan Jawa, daerah-daerah di Indonesia bagian barat, dan lain-lain.

Tidak berubahnya metode pembuatan gerabah di Bawean dalam konteks hubungan yang lama dan terus-menerus dengan daerahdaerah luar; mungkin disebabkan oleh beberapa hal. Bagi para nelayan yang membutuhkan banyak gerabah untuk wadah ikan, tentunya lebih mudah untuk membeli gerabah dari Tuban atau daerah lain. Dapat pula mereka membawa istri atau anggota keluarga lain untuk mempelajari cara pembuatan gerabah, tetapi hal ini akan merepotkan dan mengganggu kelancaran perdagangan yang mereka lakukan.

Perantau-perantau dari Bawean tidak terbatas pada nelayan atau pedagang saja, ada pula para pemuda yang mencoba mengadu nasib di rantau orang. Apabila mereka berhasil mendapat sumber kehidupan di rantau, umumnya mereka menikah dengan penduduk setempat dan jarang kembali ke daerah asal. Hal ini mungkin disebabkan karena kaum wanita umumnya jarang yang meninggalkan kampung halaman.

Di sisi lain, terdapat pula unsur-unsur budaya yang berubah karena pengaruh faktor-faktor yang telah disebutkan di atas. Sebagai contoh dapat dikemukakan bahwa sebelum abad ke-12 M di Maluku Tengah (Ambon, Haruku, dan Saparua) tidak dijumpai tempat pembuatan gerabah. Mulai abad ke-12 terjadi hubungan dagang dengan Jawa. Perdagangan reguler tersebut menyebabkan adanya inovasi yang terjadi selama 8 abad. Hal itu dapat dibuktikan dengan adanya unsur-unsur Jawa non Maluku, misalnya yang tercermin dalam bentuk gerabah (Ellen \& Glover, t.t.: 353; 365).

Contoh lain tentang perubahan budaya dapat dilihat pada kasus pembuatan gerabah di daerah pantai utara Jawa Tengah. Di dukuh Anjun, desa Malahayu, yang terletak sekitar $40 \mathrm{~km}$ di sebelah barat daya Brebes, seorang responden mengatakan bahwa kedatangannya ke daerah itu sekitar tahun 1930-an. Setelah menikah dengan wanita setempat, ia meneruskan ketrampilan yang dimilikinya, yaitu membuat gerabah seperti yang dilakukan di daerah asalnya, yaitu 
Tegal. Itulah sebabnya di daerah ini pembuatan grabah dilakukan oleh lelaki dan perempuan. Kasus sejenis terdapat pula di daerah Purbalingga. Perkawinan antar daerah menyebabkan berkembangnya tempat pembuatan gerabah di beberapa tempat.

Kasus lain dalam penyebaran pembuatan gerabah terdapat di kecamatan Pangkah, kabupaten Tegal. Beberapa orang kundi, pada tahun 1880-an didatangkan oleh sebuah pabrik gula di daerah tersebut untuk membuat gerabah, dalam usaha mencukupi kebutuhan akan gerabah. Para kundi itu didatangkan dari daerah Pemalang dan akhirnya menjadi perintis pengembangan pembuatan gerabah di daerah itu.

\section{DAFTAR KEPUSTAKAAN}

Badruddin, R. Abdurrachman. 1985. Sekilas Lintas Pulau Bawean. Yayasan Pendidikan Islam Umar Mas ud Bawean, Kab. Dati Il, Gresik.

Childe, V.G. A. 1956. Short Introduction to Archaeology. Frederick Muller Lid. London.

Ellen. Roy F. \& I.C. Glover. "Pottery Manufacture and Trade In Central Moluccas, Indonesia: The Modern Situation and the historical Implications". Man (N.S) 9. tanpa tahun.

Glover, I.C. 1968. "Pottery making in Oralan Village. Portuguese Timor". Australian National History 16 (3).

Goenadi Nitihaminoto. 1971. Gerabah Sekitar Tuban, salah satu unsur Kebudayaan Prasejarah yang masih hidup pada masa kini. Skripsi Sarjana. Belum terbit.

Nitihaminoto, G. (1980). SEBUAH CATATAN TAMBAHAN TENTANG PREHISTORI IRIAN JAYA. Berkala Arkeologi, 1(1), 1.23. https.ll doi.orgl 10.30883ljba.v1i1.273

Heekeren. H.R. Van. 1972. The Stone Age of Indonesia. The Hague Martinus Nijhoff.

Koentjaraningrat. 1981. Pengantar llmu Antropologi. Penerbit Aksara Baru. Jakarta. 
Leach, Bernard. A Potter's Book. Faber and Faber Ltd. London. tanpa tahun.

Norton, F.H. 1956. Ceramic for the Artist Potter. Addison Westly Publishing Company Inc.

Santoso Sugondo. 1981. "Pembuatan gerabah secara sederhana di desa Pulutan, Sulawesi Utara". Kalpataru i.

Schieans, Daniel J. 19i.. Filipino Market Potteries. National Museum Monograph No. 3 Manila.

Soejono, R.P. (ed). 19\%. Sejarah Nasional Indonesia I. Balai Pustaka: Jakarta.

Soejono, R.P. 1979. "Notes on Pottery Making at Berru, Cabbenge (South Sulawesi)". Seminar On Ceramic. Jakarta.

Sukarto K.A, M.M. 19;3. "Notes on Pottery Manufacture near Raba, East Sumbawa". Asian Perspective Vol. XVI (I).

Sumiati Atmosudiro. 1983. "Tradisi Pembuatan Gerabah di Nualela pulau Lomblen, Flores Timur: Suatu Tradisi Teknologi Bercocok Tanam".

Pertemuan Ilmiah Arkeologi III. Ciloto. 


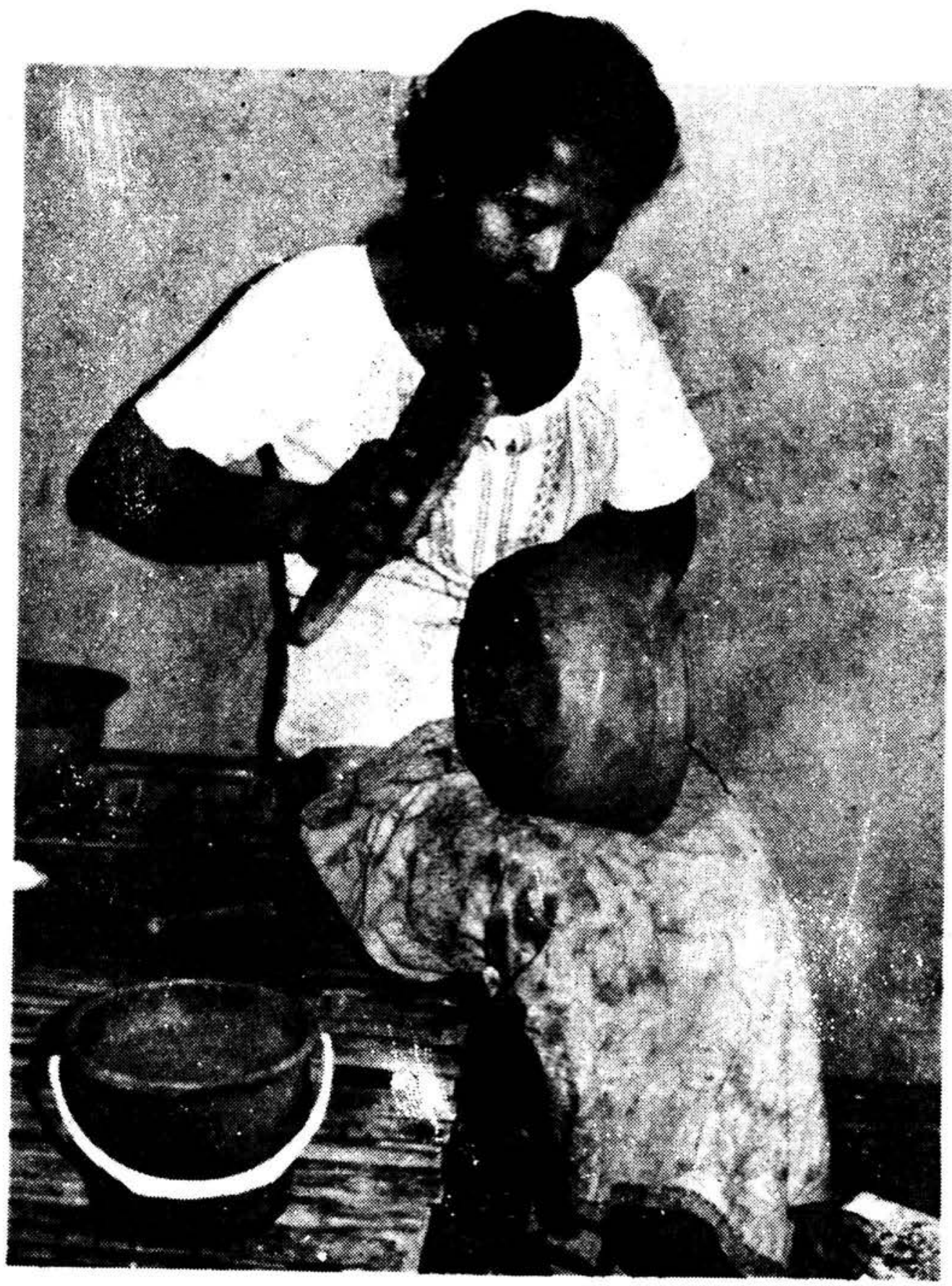

Pembuatan gerabah memakai metode tangan yang digabungkan dengan metode tatap pelandas. 


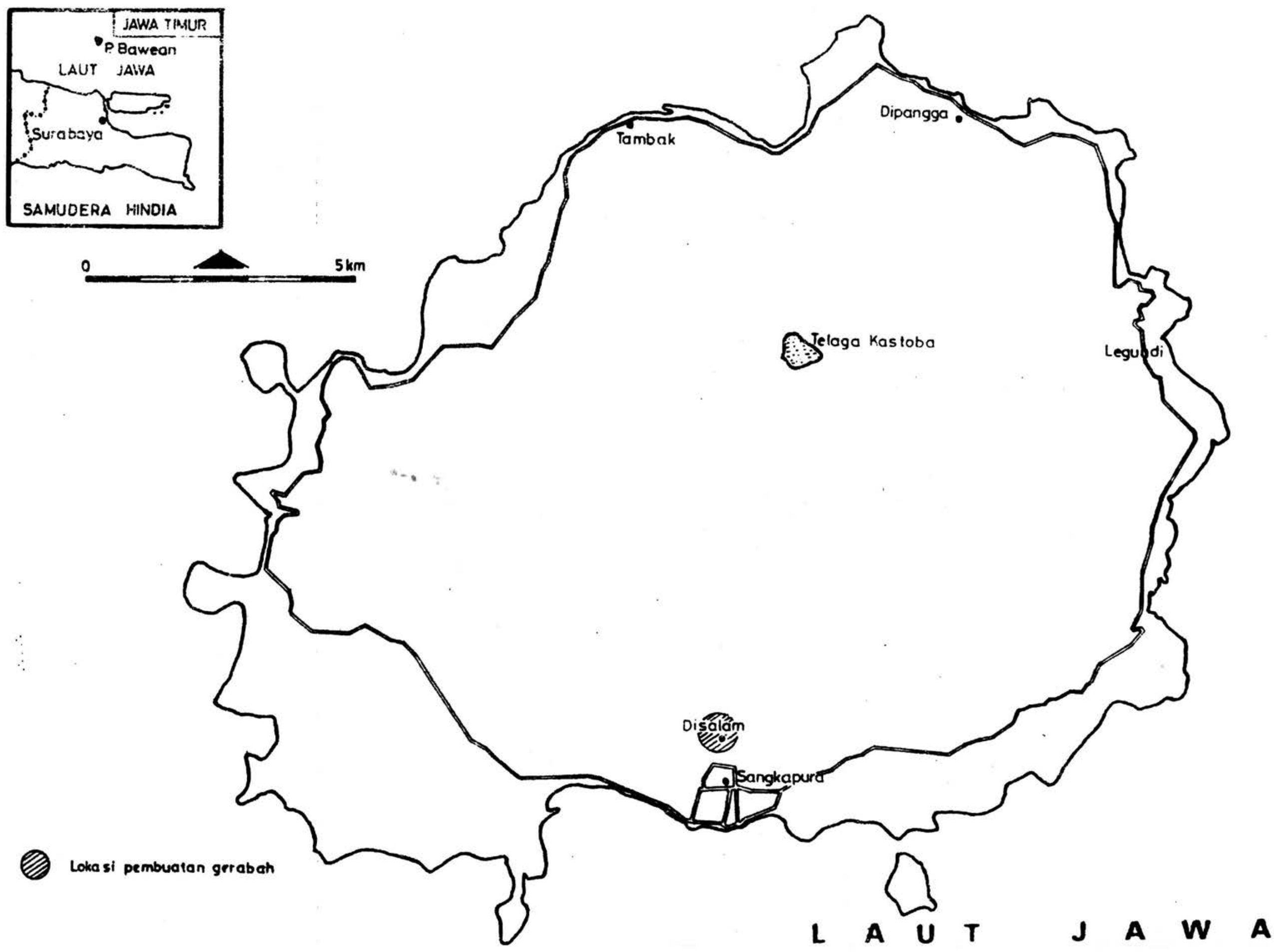



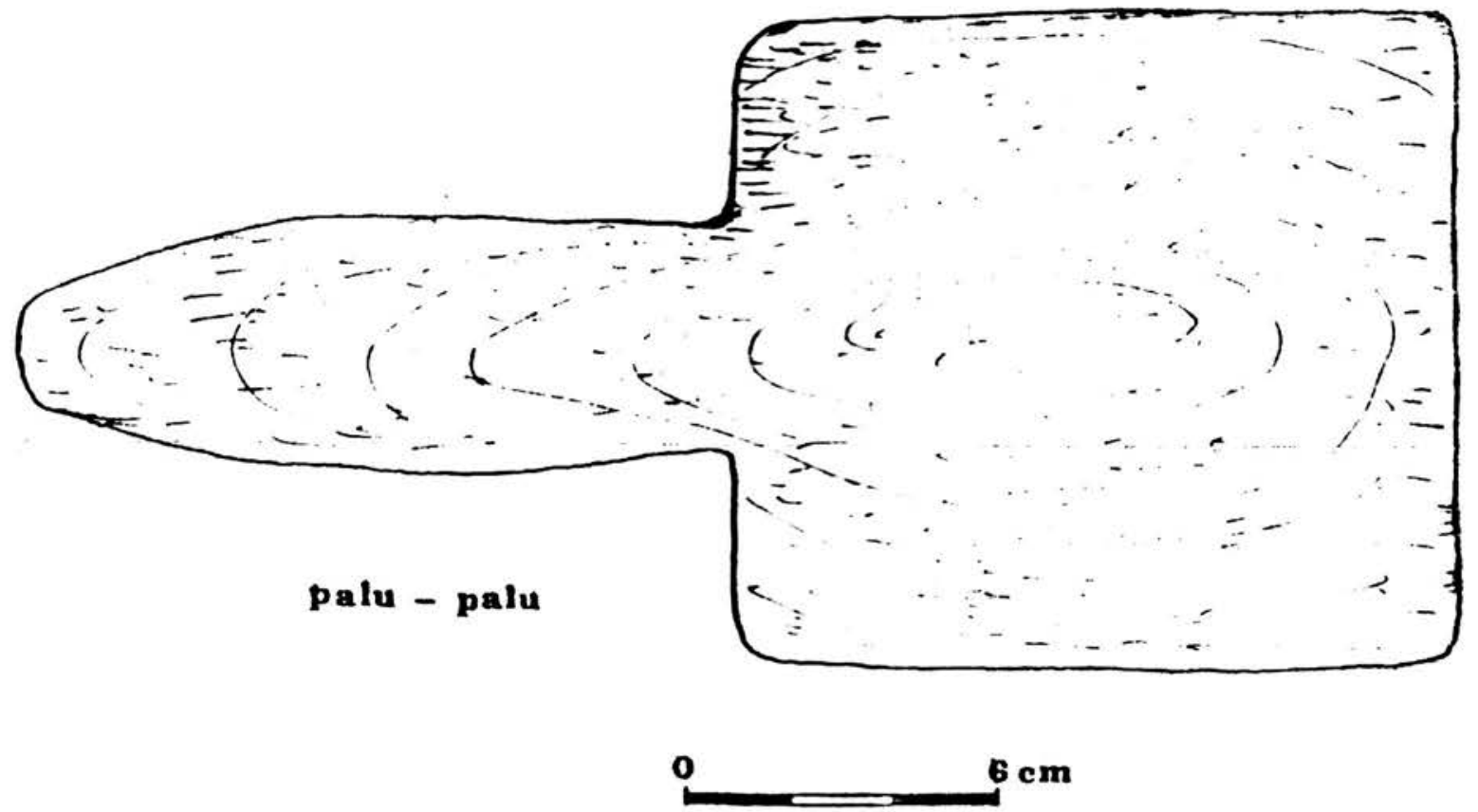

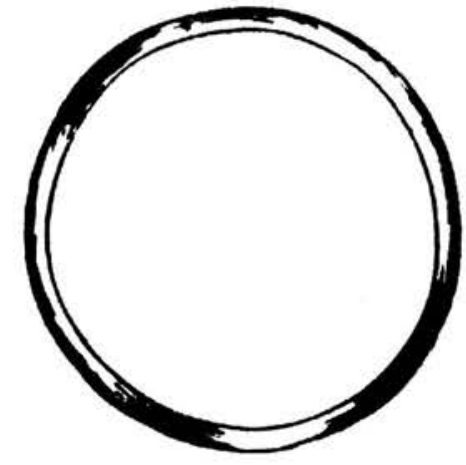

kerzk-kerèk

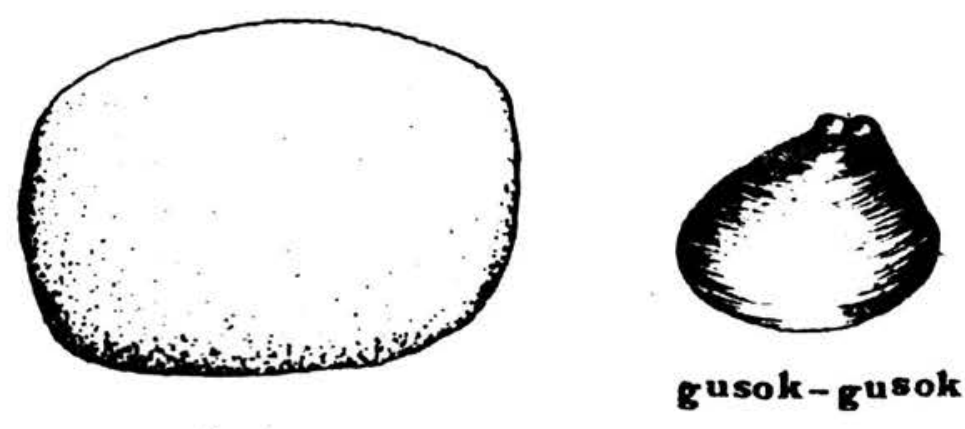

batu

Alat - alat pembuätan gerabah di pulau Bawean.

Berkala Arkeologi IX (1) 

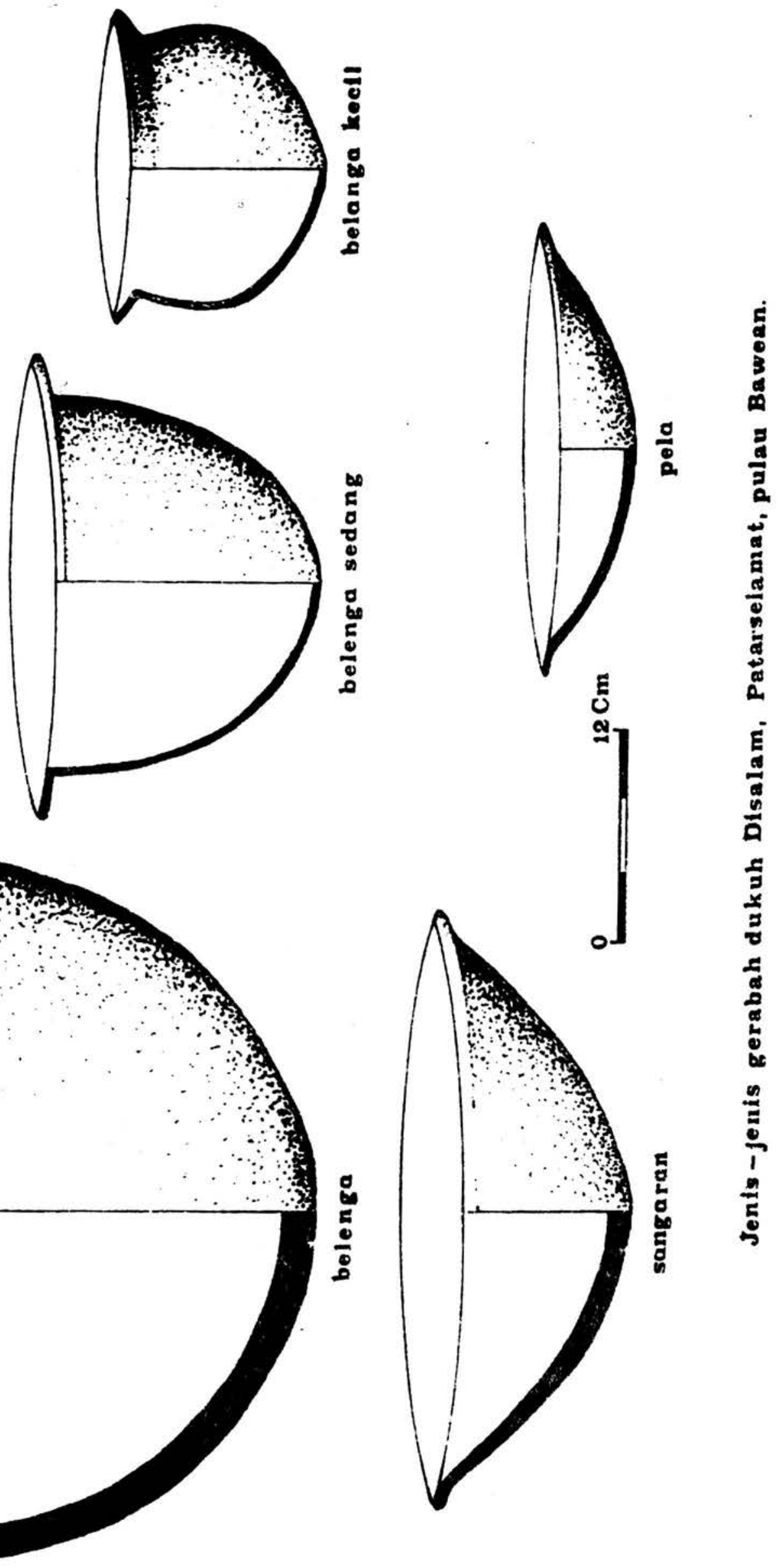

16 